Fikrah: Jurnal Ilmu Aqidah dan Studi Keagamaan

ISSN 2354-6147 EISSN 2476-9649

Tersedia online di: journal.stainkudus.ac.id/index.php/fikrah

DOI: 10.21043/fikrah.v5i1.2231

\title{
Perubahan Tatanan Hijab Mahasiswi Muslimah: Analisa Motif Dan Ideologi Keislaman
}

\author{
Sri Wahyuningsih \\ STAIN Kudus, Kudus, Indonesia \\ wahyuningsih@stainkudus.ac.id
}

\begin{abstract}
Abstrak
Artikel ini mendeskripsikan tentang tatanan hijab dan fashion dikalangan mahasiswi. Terutama mengenai motif dan ideologi keislman mereka. Penelitian ini menggunakan metode kualitatif dengan menggunakan teori pembelajaran sosial Albert Bandura. Untuk mengumpulkan data, penulis melakukan wawancara mendalam dan dokumentasi. Hasil menunjukkan bahwa mahasiswi mengalami proses peniruan tatanan hijab dan fashion yang dikenakan oleh orang lain. Mereka terlebih dahulu mengamati hijab dan fashion (attention). Tatanan model hijab dan fashion yang mereka perhatikan kemudian mereka simpan dan ingat (retention). Kemudian, mereka mulai mengenakan hijab dan busana dengan model baru (reproduction). Penampilan baru sebagai bentuk motivasi (motivation). Motif mahasiswi dalam mengikuti perkembangan fashion yaitu meniru penampilan modis orang lain sebagai manifestasi modernitas. Sebagian mahasiswi berpendapat bahwa nilai keislaman seseorang itu urusan setiap manusia dengan Allah Swt dan modis itu pilihan wanita. Sebagian mahasiswi lainnya beranggapan bahwa aspek modis dan aspek fungsi hijab sebaiknya dipadukan secara seimbang.
\end{abstract}

Kata kunci: Fashion, Hijab, Ideologi Keislaman, Motif, analisa mendalam. 


\begin{abstract}
Female Students' Hijab Style Transformation: Islamic Ideology and Motive Analysis. This article mainly describes the changes of hijab and fashion shown females students regarding to their motives and Islamic ideology. This study used a qualitative method applying a social learning theory of Albert Bandura. In-depth interviews and documentation used to collect the data. The results showed that the students had a process of imitation in terms of hijab and fashion worn by others. They observed hijab and fashion (attention). The styles of hijab and fashion they noticed is then stored (retention). Then, they began to wear the hijab and clothing with new models (reproduction). Their new appearance is a form of motivation. Some of them argued that Islamic values and faith are the affairs of every person with God and a fashionable style is a woman's choice. Meanwhile, other students thought that both fashionable style and essential functions aspects of hijab should be integrated well.
\end{abstract}

Keywords: Fashion, Hijab, Islamic Ideology, Motive, In-depth analysis

\title{
Pendahuluan
}

Setiap perkembangan fashion dan hijab selalu diikuti oleh masyarakat sebagai wujud pembeda dengan wanita lain. Hal ini senada dengan Bourdieu dalam Almila (2016a) bahwa fashion diikuti oleh masyarakat sebagai bentuk perilaku sosial untuk membedakan antara individu dan kelompok masyarakat guna memperoleh status sosial di mata orang lain. Adanya komunitas hijabers di beberapa Kota seperti Jakarta, Yogyakarta, Surabaya, Medan dan Solo merupakan contoh nyata bahwa wanita yang tergabung dalam komunitas hijabers menjadi sorotan masyarakat. Komunitas tersebut biasanya diikuti oleh followers yang nantinya mulai tertarik dan meniru gaya dan penampilan para komunitas hijabers. Adanya komunitas hijabers dapat menepis citra berhijab yang dahulu dikatakan kuno dan tidak modis. Saat ini hijab memberikan inspirasi bagi wanita muslimah sehingga mereka dapat berbusana dengan gaya modern. Sebagaimana dijelaskan oleh Beta (2014) bahwa komunitas hijaber mendeskripsikan diri mereka sebagai kelompok sosial dengan mengenakan hijab. Komunitas ini memungkinkan anggotanya untuk berkreasi dan bergaya dengan style mereka serta menghilangkan kesan kuno sehingga kesan ramah, anggun dan fashionable melekat pada diri mereka.

Beberapa studi tentang hijab dan fashion sebelumnya telah dilakukan oleh para peneliti. Bonadio \& Guimarães (2016) menunjukkan bahwa telenovela berperan penting 
dalam perkembangan fashion di Brazil. Dengan dikenalnya telenovela di kancah internasional, membuat fashion di Brazil mulai terkenal dan tersebar di luar negeri. Almila (2016b) menunjukkan bahwa wanita Muslimah di Helsinki, Finlandia menggunakan busana sebagai alat untuk mengekspresikan bentuk-bentuk modal budaya. Fashion, anti-fashion dan non-fashion adalah strategi dalam praktek-praktek tersebut, dan gaya, kesalehan, kesopanan, tidak tertarik pada fashion, dan spiritualitas adalah bentuk-bentuk modal simbolik yang digunakan untuk mendapatkan status dalam berbagai kelompok. Ünal \& Moors (2012) dengan hasil penelitiannya menunjukkan bahwa telah terjadi pergeseran dalam berhijab dan berpakaian pada wanita Turki dan Belanda karena terinspirasi dengan model dan warna gaun. Hijab tidak hanya sebagai simbol Agama, tetapi juga sebagai simbol dan identitas kelas sosial, etnik atau suku dan profesionalisme. Selain itu, hijab dan fashion juga sudah biasa dijadikan sebagai hadiah atau souvenir sehingga berbagai model hijab dan fashion mudah mereka peroleh. Hal ini merupakan salah satu pemicu yang merubah gaya hijab dan fashion wanita di Finlandia dan Belanda. Droogsma (2007) melakukan penelitian terhadap 13 orang Amerika yang menggunakan jilbab dan mendefinisikan ulang hijab dari sudut pandang teori feminist standpoint.

Berbeda dengan penelitian-penelitian sebelumnya yang subjeknya merupakan orang-orang yang tinggal di kota besar dan memiliki budaya dan latar belakang fashion yang cukup kuat, penelitian ini fokus pada perubahan gaya hijab dan fashion yang dikenakan oleh mahasiswi yang berasal dari wilayah Pantai Utara (Pantura) Jawa seperti Demak, Kudus, Pati, Jepara, Rembang dan Purwodadi. Fenomena perubahan tatanan hijab dan fashion juga terjadi di lingkungan perguruan tinggi Islam. Penampilan sebagian besar mahasiswi cenderung berubah dari waktu ke waktu. Ketika awal kuliah, penampilan mereka terkesan sederhana mulai dari hijab, baju, sepatu dan tas yang dikenakan. Akan tetapi setelah beberapa semester mereka kuliah, penampilan dan tatanan hijab dan fashion mereka mulai berubah modis, fashionable dan terkesan mementingkan aspek keindahan daripada menutupi aurat. Sebagai contoh, kain hijab yang dikenakan tipis dan menerawang sehingga rambut mereka masih terlihat, tidak menutupi dada, pakaian ketat dan mengenakan aksesoris yang tidak sesuai untuk dikenakan dilingkungan kampus. Berangkat dari fenomena tersebut, penulis tertarik 
untuk melakukan penelitian mengenai perubahan tatanan hijab dan fashion dikalangan mahasiswi. Secara spesifik artikel ini membahas motif dan ideologi keislaman mereka terhadap berubahnya berubahnya tatanan hijab dan fashion.

\section{Hijab dalam Pandangan Al-Quran}

Jilbab tidak hanya sekedar kain penutup kepala yang dikenakan di tempat tertentu. Lebih dari itu, jilbab merupakan sebuah ketentuan dan syariat yang tertera dalam al-Quran dan memiliki makna tertentu. Bagi wanita muslimah, berhijab dan memakai pakaian tertutup merupakan sesuatu yang dianjurkan dalam Islam untuk menutup aurat. Para pakar terdahulu menyebut beberapa alasan yang diduga oleh sementara orang yang mengakibatkan adanya keharusan bagi wanita untuk memakai pakaian tertutup (Shihab, 2012, hal. 42-46). Alasan pertama yaitu alasan filosofis yang berpusat pada kecenderungan ke arah kerahiban dan perjuangan melawan kenikmatan dalam rangka melawan nafsu manusiawi. Alasan ini menunjukkan bahwa wanita adalah bentuk tertinggi kesenangan. Jika seorang lelaki diberi kesempatan untuk melihat tubuh perempuan secara terbuka, maka pandangan lelaki tersebut secara otomatis tertuju pada tubuh wanita tersebut sehingga menimbulkan rasa suka dan membangkitkan hawa nafsu. Hal ini berdampak pada maraknya kegiatan negatif dan merosotnya kemajuan suatu masyarakat. Alasan kedua yaitu alasan keamanan dan alasan ketiga yang diduga oleh sementara orang sebagai penyebab lahirnya pakaian tertutup serta menghalangi wanita ke luar rumah adalah alasan ekonomi.

Terlepas dari pendapat para pakar terdahulu sebagaimana diungkapkan oleh Shihab (2012), al-Quran dan hadis telah menjelaskan tentang pakaian dan memberi arahan menyangkut cara-cara memakainya. Adapun ayat-ayat al-Quran yang menjelaskan tentang pakaian diantaranya adalah Qs. al-A'raf ayat: 26 yang artinya:

"Wahai anak Adam, sesungguhnya Kami telah menurunkan pakaian untuk menutupi auratmu dan pakaian indah sebagai perhiasan. Sedangkan pakaian takwa itulah yang lebih baik. Yang demikian itu adalah sebahagian dari tanda-tanda kekuasaan Allah, mudah-mudahan mereka selalu ingat." (Qs. alA'raf: 26).

Surah al-A'raf ayat 26 menunjukkan bahwa fungsi pakaian adalah alat untuk menutup aurat, yakni hal-hal yang tidak sepatutnya dilihat oleh orang lain dan rawan 
bahaya. Fungsi pakaian selanjutnya adalah sebagai hiasan bagi pemakainya. Seseorang terlihat indah dengan balutan pakaian yang rapi dan sopan. Begitupula para wanita muslimah, mereka terlihat indah, cantik dan menawan apabila memakai pakaian rapi dan sopan. Lebih dari itu, seorang wanita muslimah tidak hanya cukup menghias diri mereka melalui pakaian. Di balik pakaian indah yang dikenakannya, hendaknya disertai dengan ketaqwaannya kepada Allah SWT dengan mematuhi segala perintah-Nya dan menjauhi segala larangan dan kemaksiatan. Dengan kata lain, Surah al-A'raf ayat 26 mengisyaratkan pada wanita muslimah untuk senantiasa menjaga keindahan lahir dan batin. Selanjutnya adalah Qs. al-Ahzab ayat 59, yang artinya:

"Hai Nabi, Katakanlah kepada isteri-isterimu, anak-anak perempuanmu dan isteri-isteri orang mukmin: "Hendaklah mereka mengulurkan jilbabnya ke seluruh tubuh mereka". Yang demikian itu supaya mereka lebih mudah untuk dikenal, karena itu mereka tidak diganggu. Dan Allah adalah Maha Pengampun lagi Maha Penyayang”.

Surat al-Ahzab ayat 59 menunjukkan bahwa wanita muslimah dianjurkan untuk memakai jilbab sebagai penutup aurat dan sebagai identitas diri muslimah sekaligus sebagai pembeda antara seseorang dengan selainnya dalam sifat atau profesinya. Dalam hal menutup aurat, wanita muslimah harus mampu memadukan antara fungsi pakaian sebagai hiasan dan fungsi pakaian sebagai penutup aurat. Mereka tidak dibolehkan mengabaikan ketertutupan aurat demi sesuatu yang menurut mereka indah dan menawan. Apabila mereka mengenakan pakaian yang indah tetapi tidak mampu menutup aurat, maka berdampak negatif baik bagi wanita tersebut maupun bagi yang melihatnya. Oleh karenanya, antara unsur keindahan dan fungsi penutup aurat sebaiknya dapat diperankan secara ideal. Sebagai seorang muslimah berhijab tidak hanya sekedar menutup bagian kepala dengan sehelai kain. Lebih dari itu, berhijab merupakan bentuk ketakwaan kepada Allah SWT yang mengandung makna kemuliaan, kesucian, dan perlindungan dari segala hal yang mengarah pada kemaksiatan.

\section{Tren Fashion Islam di Indonesia}

Kemajuan teknologi membuat masyarakat lebih mudah dan terbuka untuk mengakses pengetahuan global. Hal ini merupakan salah satu dampak globalisasi yang 
telah merambah ke berbagai aspek salah satunya adalah dunia fasion Islam. Fashion Islam di Indonesia sekarang banyak dipengaruhi oleh budaya barat dan timur tengah. Misalnya: Busana Gamis, Kaftan, Abaya yang dahulu hanya dipakai wanita di Timur Tengah, sekarang sudah merajalela dipakai oleh wanita muslimah di Indonesia. Model baju gamis tersebut dipakai untuk menunjukkan transformasi mode atau fashion pada penampilan individu. Hal ini menunjukkan bahwa kecangggihan teknologi membuat para desainer dan pemilik butik Muslim di Indonesia semakin modern dan up to date dalam berkreasi dan berinovasi terhadap karyanya. Sehingga fashion, tren atau mode akan terus berubah mengikuti perkembangan zaman. Suatu mode akan hilang, dengan sendirinya seiring munculnya mode baru. Lebih lanjut, gagasan Bourdieux yang dikutip Almila (2016a) menegaskan bahwa fashion diikuti oleh masyarakat sebagai bentuk perilaku sosial untuk membedakan antara individu dan kelompok masyarakat guna memperoleh status sosial di mata orang lain.

Keberadaan media sosial memudahkan wanita muslimah mengakses model atau tren hijab dan busana terbaru. Wanita Muslimah (Hijaber) biasanya merupakan pengguna media sosial aktif seperti Facebook, Twitter, Instagram, dan Blog fashion yang dijadikan sebagai referensi, model, pilihan dan konstruksi identitas diri di kalangan wanita muda (Rocamora, 2012). Selain aspek media sosial, aspek budaya dan nilai simbol juga berpengaruh terhadap tatanan hijab dan fashion seseorang. Sebagaimana diungkapkan oleh Crane dan Bovone dalam Almila (2016b) bahwa busana dapat diartikan sebagai sebuah nilai simbol yang melekat pada objek materi seperti kelas sosial, gaya hidup dan relasi kelompok. Oleh karenanya, busana, fashion dan antifashion sangat erat dikaitkan dengan simbol kapital dan budaya. Modal atau kapital budaya biasanya melekat pada tindakan dan bahasa tubuh seperti pose, gerakan dan penampilan. Lebih lanjut, kapital budaya juga bisa diwujudkan dalam bentuk perhiasan atau aksesoris. Dengan kata lain, pakaian dan cara mengenakan pada tubuh merupakan bentuk modal budaya. Dengan modal budaya, seseorang terlihat menawan, modis serta dihargai orang lain. Dengan adanya pengakuan dari orang lain, modal budaya menjadi simbol dan memiliki potensi untuk memberikan status sosial bagi seorang wanita. Bukti nyata perkembangana fashion muslimah di Indonesia dapat dilihat dari penggunaan 
corak dan warna yang bervariasi. Zaman dahulu busana muslimah dan hijab identik dengan sesuatu yang sederhana dan polos dan menggunakan warna yang standar seperti putih dan hitam (dapat dilihat pada Gambar 1). Hal ini berbeda dengan era sekarang, wanita muslimah lebih berani memakai busana yang lebih modis dan berwarna serta dilengkapi dengan berbagai aksesoris seperti jam tangan, ikat pinggang rantai, gelang, bros, sepatu, dan sebagainya. Selain itu, munculnya tutorial hijab modern di media sosial membuat wanita muslimah mudah mengakses dan meniru gaya hijab terkini. Gambar 1 menunjukkan perkembangan awal model jilbab di Indonesia.

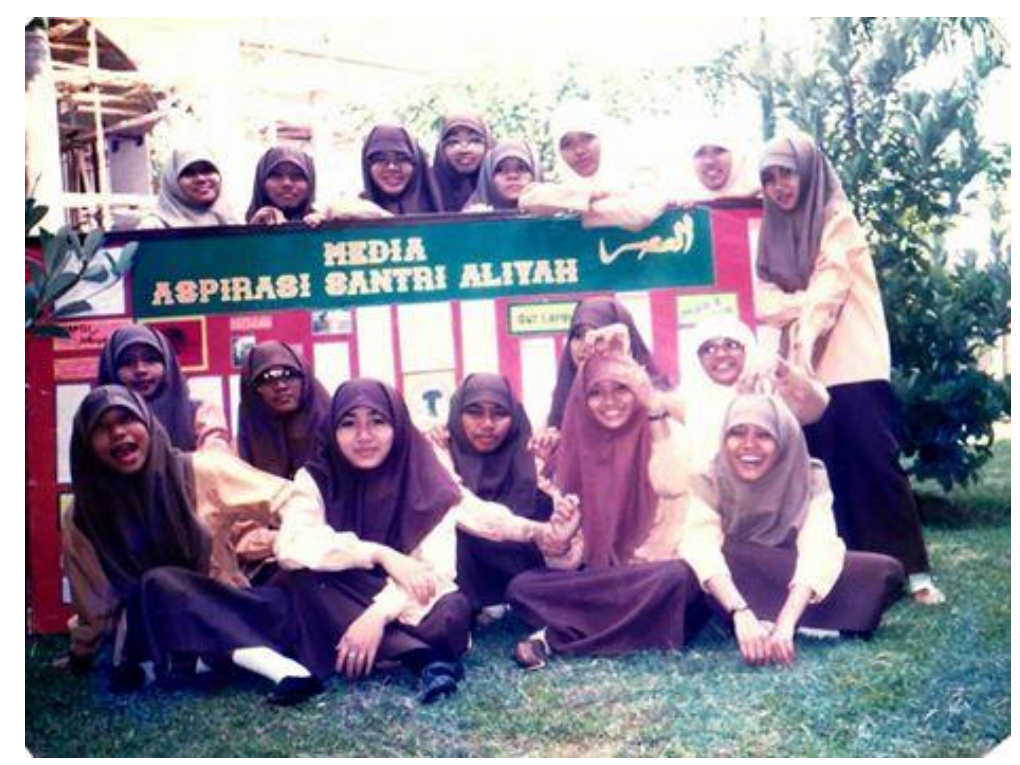

Gambar 1 Pemakaian hijab dengan model sederhana (Sumber: Dokumentasi Penulis)

\section{Gaya Hijab Muslimah dan Konsumerisme Masif}

Pesatnya perkembangan hijab dan fashion Islam memberikan dampak pada usaha komersil. Konsumen dihadapkan pada situasi maraknya berbagai produk dan tampilan hijab yang bervariasi dan trendi. Untuk menarik perhatian konsumen, hijab dan fashion terbaru sengaja ditampilkan di patung baju (Manekin) oleh para pengusaha, perancang busana dan hijab. Mereka menyuguhkan berbagai macam kualifikasi hijab diantaranya jilbab kotak, bergaris, manik-manik, jilbab musim panas, dan sebagainya dilengkapi dengan corak dan warna. Selain memajang hijab dan busana di patung baju (manekin), para pengusaha hijab dan fashion menggunakan media sosial seperti 
facebook, Blog, WhatsApp, Blackberry Messanger untuk memasarkan bisnis mereka atau disebut dengan istilah online shopping. Munculnya bisnis online shopping ini memberikan kenyamanan dan kemudahan bagi para konsumen khususnya wanita muslimah untuk mengakses dan membeli produk hijab dan fashion muslimah. Di sisi lain, online shopping juga memiliki kekurangan dan dampak negatif bagi konsumen. Kekurangan dari online shopping diantaranya dapat memicu aksi penipuan oleh penjual kepada konsumen misalnya setelah transaksi pembayaran dilakukan oleh konsumen, penjual tidak jadi mengirim barang yang dijual. Kekurangan selanjutnya yaitu konsumen tidak dapat melihat, menyentuh, mencoba dan memakai produk secara langsung sehingga kualitas barang yang dibeli tidak sesuai dengan harapan konsumen. Dalam hal ini penjual dan pengusaha fashion dan hijab cenderung fokus pada tampilan atau visualitas produk mereka.

Ekslusifitas pada tampilan hijab dan busana dapat menimbulkan suatu masalah. Hal ini dikarenakan mengenakan hijab dan busana tidak hanya melibatkan aspek visual melainkan juga aspek sentuhan, rasa, dan kenyamanan (Arzu Ünal \& Moors, 2012). Sentuhan inilah yang menjadikan pembeda antara online shopping dengan offline shopping. Misalnya ketika konsumen melakukan offline shopping, mereka dapat melihat sekaligus menyentuh kain dan materi dari hijab dan busana apakah kain itu halus atau kasar, panas atau dingin, nyaman atau tidak. Selain itu, mereka juga dapat mencoba busana dan hijab di tempat yang tidak bisa mereka lakukan ketika melakukan online shopping.

Untuk menutupi kekurangan online shopping, penjual biasanya mensiasati dengan menyebutkan nama atau jenis, ukuran, tekstur, warna, pola dan hiasan hijab dan busana, mendeskripsikan tentang materi, dan menampilkan gambar produk secara detail sehingga memudahkan konsumen untuk memperbesar gambar hijab dan busana serta memiliki pandangan tentang produk tersebut. Lebih lanjut, dalam menjalankan usaha online shopping, konsep kepercayaan (trust) seperti terbuka, jujur, sopan harus terbangun antara penjual dan konsumen karena mereka adalah komunitas online (virtual) yang memberikan kontribusi pada hubungan dan interaksi sosial. Sebagaimana yang ditekankan oleh Alyusi (2016, hal. 49) bahwa timbulnya rasa percaya yang terjalin 
antar anggota komunitas virtual diawali dengan sikap keterbukaan, kejujuran, kesopanan, dan kesetiaan. Pada tingkatan komunitas, sumber-sumber kepercayaan (trust) berasal dari Norma sosial yang memang melekat pada struktur sosial setempat.

Selain memasarkan produk hijab dan fashion muslimah secara daring, cara dan strategi lain yang dilakukan para pengusaha hijab dan busana juga gencar menggelar bazar dan pameran fashion di berbagai tempat umum seperti pusat perbelanjaan (mall), kampus, alun-alun, pusat kegiatan keagamaan dan sebagainya. Dengan adanya pameran dan bazar fashion dan hijab, banyak wanita muslimah baik muda maupun tua menjadi tertarik mengunjungi dan membeli beraneka ragam model hijab dan busana yang dipamerkan. Lebih lanjut, wanita muslimah khususnya remaja yang semula tidak berhijab menjadi tergiur untuk mengenakan hijab dengan munculnya bazar dan pameran hijab dan fashion. Para mahasiswi pun sekarang memiliki banyak model dan pilihan dalam berbusana untuk menunjukkan identitas mereka. Hal ini senada dengan pernyataan (Lewis, 2007, hal. 435) yang mendeskripsikan bahwa pilihan busana muslimah menjadi penanda pengetahuan dan identitas mereka yang membedakannya dengan wanita lain.

Fenomena hijabers tidak hanya terjadi di Indonesia. Di Amerika pun beberapa kontes model hijab digelar. Berbagai media ikut andil untuk meramaikan dunia fashion dan hijab seperti Blog, Instagram, Youtoube dan sebagainya. Bukti meningkatnya budaya hijab dan fashion di Amerika adalah munculnya berbagai butik khusus busana muslim, masjid yang mensponsori pergelaran fashion dan busana muslimah, dan penjualan hijab secara online (Chen, Akat, Xin, \& Song, 2014, hal. 209). Barnard dalam (Chen et al., 2014), menambahkan bahwa maraknya dunia fashion tidak terlepas dari fungsi busana baik fungsi material (bahan) maupun fungsi budaya. Adapun fungsi material sebuah busana yaitu perlindungan, kesopanan, dan daya tarik. Sedangkan fungsi budaya dari busana atau fashion meliputi komunikasi, ekspresi individu, status sosial, peran ekonomi, simbol politik, kondisi keagamaan, ritual sosial, dan rekreasi. Pendapat para pakar di atas dapat diartikan bahwa perkembangan hijab dan fashion tidak hanya sekedar trend, artinya hijab dan fashion memiliki makna dan fungsi tersendiri bagi orang yang memakai baik itu fungsi material maupun fungsi budaya. 
Seiring berkembangnya hijab dan fashion Islam di Indonesia membuat model hijab semakin fashionable sehingga menarik perhatian wanita muslimah untuk tampil berhijab dengan modis dan anggun. Selain itu, ada alasan fundamental memakai hijab yaitu hijab merupakan sesuatu yang dianjurkan dalam al-Qur'an dan hadis yaitu berfungsi sebagai penutup aurat. Lebih lanjut, hijab dikenakan sebagai simbol identitas wanita muslimah yang membedakan mereka dengan wanita non muslimah. Sebagaimana telah dijelaskan dalam al-Qur'an surat An-nur ayat 31:

"Hendaklah mereka menahan pandangannya, dan kemaluannya dan janganlah mereka menampakkan perhiasannya, kecuali yang (biasa) nampak dari padanya. Dan hendaklan mereka menutupkan kain kerudung ke dadanya, dan janganlah menampakkan perhiasannya, kecuali kepada suami mereka, atau ayah mereka atau ayah suami mereka atau putera-putera mereka atau putera-putera suami mereka, atau saudara-saudara laki-laki mereka, atau putera-putera saudara lelaki mereka, atau putera-putera saudara perempuan mereka, atau wanitawanita islam atau budak-budak yang mereka miliki, atau pelayan-pelayan lakilaki yang tidak mempunyai keinginan (terhadap wanita) atau anak-anak yang belum mengerti tentang aurat wanita. Dan janganlah mereka memukulkan kakinya agar diketahui perhiasan yang mereka sembunyikan. Dan bertaubatlah kamu sekalian kepada Allag, Hai orang-orang yang beriman supaya kamu beruntung."

Selain al-Qur'an, anjuran berhijab bagi wanita muslimah juga dijelaskan dalam hadis yang diriwayatkan oleh Abu Daud yang artinya sebagai berikut:

Dari Khalid bin Duraik: "Aisyah RA, berkata: 'Suatu hari, asma binti abu bakar menemui Rasulullah SAW dengan menggunakan pakaian tipis, beliau berpaling darinya dan berkata: "wahai asma" jika perempuan sudah mengalami haid, tidak boleh ada anggota tubuhnya yang terlihat kecuali ini dan ini, sambil menunjuk ke wajah dan kedua telapak tangan.” (HR. Abu Daud).

Penjelasan di dalam al-Qur'an dan hadis di atas nampak jelas bahwa wanita muslimah dianjurkan untuk menutup aurat mereka. Merujuk pada anjuran tersebut dan berkembangnya model hijab dan fashion Islam di Indonesia, maka tidak sedikit wanita muslimah mulai mengenakan hijab dengan berbagai model sesuai dengan keinginan mereka bahkan membentuk sebuah kelompok wanita berhijab yang dikenal dengan komunitas hijaber. 
Komunitas hijaber merupakan sebuah komunitas yang terdiri atas sekelompok wanita yang memiliki kesamaan visi atau pandangan dalam bergaya, berhijab dan berbusana. Di Indonesia terdapat beberapa komunitas hijabers yang tersebar di beberapa kota diantaranya komunitas hijabers Jakarta, Komunitas Hijaber Surabaya, komunitas hijabers Solo, komunitas hijabers Medan, dan sebagainya. Setiap komunitas tentunya memiliki pengikut atau followers' dengan jumlah yang cukup banyak. Disamping sebagai wadah untuk berkreasi dalam berhijab dan berbusana, komunitas hijabers biasanya juga mengadakan kegiatan-kegiatan bersifat positif seperti diskusi keagamaan, pengajian dan gelar amal, information sharing, fashion show, talk show, dan lain-lain. Dengan adanya kegiatan-kegiatan tersebut, secara bertahap komunikasi kelompok yang terjalin dalam komunitas hijabers dapat berdampak pada pribadi setiap individu yang terlibat di dalam kelompok. Rasa percaya diri mereka pun muncul dan meningkat setelah bergabung dengan komunitas hijabers. Tentu saja ada hal-hal yang melatarbelakangi meningkatnya kepercayaan diri komunitas hijabers diantaranya adanya rasa nyaman dan bangga menjadi anggota hijabers yang menunjukkan status sosial, memperoleh teman-teman yang memiliki tujuan sama dalam berhijab, adanya pertukaran informasi (information sharing) membuat wawasan dan pengetahuan baik mengenai dunia fashion maupun tentang keagamaan semakin dalam dan luas, dan memiliki gaya berhijab dan fashion secara anggun, elegan dan modis yang sepadan dengan teman-teman komunitas hijabers sehingga dapat menjadi pusat perhatian dan ditiru oleh wanita muslimah lain.

\section{Metode Penelitian}

Penelitian ini menggunakan metode penelitian kualitatif dengan pendekatan pada analisis deskriptif yang bertujuan untuk menggambarkan fenomena tentang hijab, fashion, budaya modernitas. Subjek penelitian ini adalah mahasiswi STAIN Kudus Jurusan Pendidikan Guru Roudhotul Athfal (PGRA) sebanyak lima mahasiswi.Untuk mengumpulkan data, penulis menggunakan penelitian lapangan berupa wawancara mendalam (in-depth interview) dan dokumentasi. Setelah data terkumpul, maka dilakukan analisis data dengan menggunakan metode analisis data kualitatif model 
interaktif yang meliputi: pengumpulan data, reduksi data, penyajian data, dan penarikan kesimpulan.

\section{Hasil dan Pembahasan}

\section{Hijab dan Fashion di Kalangan Mahasiswi STAIN Kudus}

Berkembangnya hijab dan fashion Islam telah memberikan pengaruh bagi mahsiswi STAIN Kudus dalam berhijab dan mengenakan fashion muslimah terutama mahasiswi jurusan PGRA. Mereka yang dahulu tidak mengenal dunia fashion dan hijab, setelah masuk dunia perkuliahan sebagian besar mahasiswi menjadi semakin familiar, terampil dan modis dalam berhijab dan berbusana sehingga tampilan mereka tidak terkesan kuno. Hal ini terbukti dengan banyaknya koleksi model hijab dan busana seperti gamis, kardigan dan rok yang dimiliki oleh para mahasiswi. Penampilan mereka berubah menjadi trendy dan terinspirasi dari berbagai model hijab. Sebagaimana yang diungkapkan oleh MK mengenai penampilan hijab dan fashion teman - teman sekelasnya yakni jurusan PGRA:

"Sebagian besar teman sekelas saya mulai berubah dalam berpenampilan. Secara perlahan mereka mulai mengikuti Tren hijab dan fashion. Mereka mulai bisa menggunakan hijab dengan berbagai model meliputi segi empat, phasmina, dan sebagainya. Selain itu untuk mempercantik tampilan hijab, biasanya mereka melengkapi dengan aksesoris seperti Bros, Head piece, pita dan sebagainya untuk menambah rasa percaya diri". (Wawancara dengan MK, 25 Januari 2017).

Hal senada diungkapkan oleh UL yang secara ekspilisit menjelaskan bahwa mahasiswi STAIN Kudus terutama jurusan PGRA penampilannya cukup sopan. Beberapa mahasiswi berpenampilan sederhana dan sebagian lainnya berpenampilan modis dan fashionabel.

"Dilihat dari latar belakang daerah, mahasiswi STAIN Kudus mayoritas berasal dari wilayah PANTURA yakni Demak, Kudus, Pati, Rembang, dan Grobogan. Dalam hal berpakaian, penampilan mereka dikatakan masih wajar dan tidak melampaui batas. Pada awal masuk bangku kuliah penampilan dari teman-teman masih lugu dan sederhana dengan mengenakan hijab segi empat, tidak dihiasi aksesoris. Setelah semester dua penampilan teman-teman mulai berubah misalnya mulai mengenakan hijab phasmina, segi empat dengan 
model baru, bahkan mereka mulai mengenakan gamis dan kardigan agar terlihat modis". (wawancara dengan UL, 25 Januari 2017)

Berdasarkan hasil wawancara dengan UL terlihat jelas bahwa sebagian besar penampilan mahasiswi STAIN Kudus terutama jurusan PGRA mulai berubah menjadi modis. Mereka terinsipirasi dengan teman sekelas dan mahasiswi dari jurusan lain yang berpenampilan modis dan kekinian. Selain itu, adanya tutorial hijab di media sosial semakin membuat mereka mudah berkreasi dalam mengenakan hijab sehingga tidak terlihat monoton dan kuno dalam berhijab. Sebagian dari mereka bahkan ada yang beranggapan bahwa untuk tampil modis tidak harus mahal. Tampilan modis dapat dikemas dengan memadukan warna antara baju, hijab, sandal, sepatu dan aksesoris sehingga terlihat serasi dan enak dipandang. Satu hal yang penting dalam menentukan penampilan seseorang adalah rasa percaya diri setiap orang. Semodis dan semahal apapun penampilan seseorang jika tidak diimbangi dengan rasa percaya diri, maka penampilannya tidak enak atau nyaman dipandang. Dengan kata lain, seseorang yang berpenampilan simpel dan tidak berlebihan apabila memiliki rasa percaya diri telihat nyaman dan enak ketika dilihat orang lain.

ND, salah satu mahasiswi, secara jelas mengungkapkan bahwa rasa percaya diri sangat menentukan indah dan tidaknya penampilan seseorang.

"Mahasiswi teman-teman sekelas saya sebagian besar sangat pandai dalam berdandan, berbusana dan berhijab dengan berbagai model. Hanya beberapa teman saja termasuk saya yang tidak neko-neko dalam berhijab dan setia menggunakan kerudung segi empat. Saya merasa tidak percaya diri dan kurang nyaman jika menggunakan hijab dengan model-model baru. Saya juga tidak pernah memakai gamis atau kardigan sebagaimana yang dipakai oleh teman-teman ketika kuliah". (Wawancara dengan ND, 25 Januari 2017).

Ada beberapa hal atau faktor yang melatarbelakangi perubahan penampilan yang dialami oleh sebagian besar mahasiswi STAIN Kudus. Faktor-faktor tersebut antara lain:

\section{Faktor lingkungan}

Lingkungan merupakan faktor yang memiliki pengaruh kuat terhadap perkembangan hijab dan fashion di kalangan mahasiswi. Mahasiswi yang awalnya tidak 
mengenal fashion menjadi up to date terhadap perkembangan hijab dan fashion setelah berbaur dengan teman-teman di lingkungan kampus. Misalnya: mahasiswi yang berasal dari daerah PANTURA seperti Demak, Kudus, Pati, Rembang, Grobogan mulai ada perubahan dalam berpenampilan meskipun tidak semua mahasiswi mau merubah penampilannya. Perubahan penampilan mereka dapat dilihat dari cara mereka berhijab yang mulai menggunakan phasmina dengan model baru, memakai rok panjang dengan baju masuk, dan memakai kardigan panjang. Perubahan tersebut muncul karenanya adanya model atau icon yakni teman sekelas dan teman dari jurusan lain yang berpenampilan modis dan fashionable sehingga membuat teman-teman mereka mulai mengikuti dan mencoba berpenampilan baru dan modern.

\section{Faktor ekonomi}

Status ekonomi ternyata juga berpengaruh terhadap penampilan dan gaya berbusana seseorang. Tegaskan oleh Rafferty dalam Almila (Almila, 2016a) bahwa seseorang berstatus sosial tinggi (higher class) biasanya cenderung lebih percaya diri dalam memadukan fashion dibandingkan dengan orang yang berstatus rendah (lower class). Hal ini berlaku juga bagi mahasiswi STAIN Kudus khususnya jurusan PGRA. Mereka yang berasal dari keluarga berada rata-rata memiliki rasa percaya diri yang kuat dalam berbusana dan berhijab. Setiap hari penampilannya selalu berubah mulai dari pakaian, hijab dengan berbagai model, tas, sepatu dan aksesoris bermerk. Sedangkan mahasiswi yang berasal dari ekonomi menengah ke bawah dan dari daerah pedesaan yang jauh dari perkotaan cenderung terlihat lugu dan kaku bahkan kurang percaya diri dalam berpenampilan.

"Teman sekelas saya ada yang menjadi model hijab dan fashion di daerah kudus dan Jepara namanya Aldila. Dia memang berasal dari keluarga berada. Dari awal masuk kuliah semester pertama, penampilannya sudah terlihat modis dan berbeda dari teman-teman yang lain. Selain itu, dia orangnya sangat percaya diri dalam memadukan busana, hijab, sepatu dan tas. Warnanya pun juga selaras dan menarik". (wawancara dengan MF, 25 Januari 2017). 


\section{Faktor budaya}

Fenomena berhijab di kalangan mahasiswi juga dipengaruhi oleh budaya setempat. Budaya berhijab telah melekat masyarakat di wilayah PANTURA seperti Demak, Kudus, Pati, Rembang yang sebagian besar masyarakatnya beragama islam. Banyaknya pondok pesantren dan tempat pendidikan bernuansa islam seperti TPQ, Madrasan Diniyah, Madrasah Tsanawiyah (MTs), Madrasah Aliyah (MA) membuat masyarakat setempat terbiasa dengan budaya hijab. Rutinitas mengenakan hijab menjadi salah satu alasan bagi wanita terutama mahasiswi STAIN Kudus untuk pandai dan terampil dalam mengenakan hijab dan busana supaya tidak terlihat monoton dan kuno. Lebih dari itu, budaya hijab di dunia pendidikan bernuansa islami seperti STAIN Kudus marak terjadi di kalangan mahasiswi. Sebagian mahasiswi berkreasi dalam berbusana dan berhijab sehingga menarik perhatian mahasiswi lain untuk meniru gaya berhijab. Selain di dunia pendidikan, budaya hijab marak terjadi di dunia kerja seperti perusahaan, toko, mall, rumah sakit dan sebagainya. Hal itu menunjukkan bahwa gaya atau fashion islami sekarang dapat dikenakan oleh para wanita muslimah di berbagai aktivitas secara modis tidak hanya terbatas pada dunia pendidikan.

\section{Peran Media Sosial dalam Perkembangan Hijab dan Fashion di Indonesia}

Berkembangnya hijab dan fashion tidak terlepas dari peran media sosial yang viral di era globalisasi. Fashion islami kini secara modis dipadukan dengan cantik oleh wanita muslimah. Mereka mampu memadukan fashion dengan berbagai merek, memainkan warna, melengkapi tas dan sepatu, memperindah dengan aksesoris dan sebagainya. Melalui media sosial khususnya internet, segala sesuatu dapat diakses dengan mudah termasuk perkembangan fashion dan hijab. Para pengusaha hijab dan fashion pun ikut memanfaatkan media sosial dalam memasarkan produknya (Boulanouar, 2006). Adapun mendia sosial yang digunakan oleh mereka antara lain Facebook, Instagram, BBM, Whats up dan Blog yang dibuat secara khusus untuk berjualan hijab dan busana secara online dan terdiri atas sekelompok orang yang bergabung di dalamnya. Cara tersebut dirasa sangat efektif dan mudah dalam menjual hijab dan busana. 
Selain itu, maraknya online shopping ternyata dapat berpengaruh terhadap perkembangan hijab dan fashion yang dikenakan oleh para wanita di era sekarang. Berbagai model hijab dan busana setiap hari diupload atau diposting oleh penjualnya sedemikian rupa sehingga menarik perhatian orang yang melihat dan menimbulkan keinginan untuk membeli. Dengan adanya postingan di media sosial, para wanita termasuk mahasiswi STAIN Kudus dapat mengetahui perkembangan hijab dan fashion yang selalu berubah dari waktu ke waktu dan secara otomatis penampilan mereka pun menjadi modis mengikuti fashion terkini. Sebagaimana diungkapkan oleh Miskiyah, salah satu Mahasiswi Jurusan PGRA di STAIN Kudus selaku penjual hijab dan busana melalui online shopping:

"Di sela-sela kuliah, saya memanfaatkan waktu untuk berjualan hijab dan busana melaui online shopping. Setiap hari saya memposting model hijab dan busana yang sedang Trend dipakai oleh para wanita sekarang. Untuk mengetahui perkembangan fashion saya bergabung dengan komunitas atau produsen hijab dan fashion melaui media sosial seperti BBM, Instagram, dan Facebook. Saya juga rajin mencari tahu model fashion terbaru melalui Blog atau Instagram milik para pengusaha butik dan Fashion seperti Zaskia Sungkar dan Dian Pelangi. Selain itu, saya juga mengamati fashion dan gaya hijab yang dikenakan oleh para artis muslimah sehingga saya dapat menjelaskan kepada pelanggan saya mengenai fashion". (Wawancara dengan MS, 25 Januari 2017).

Di kalangan para mahasiswi STAIN Kudus, terutama jurusan PGRA, setiap perkembangan model hijab dan busana selalu diikuti melalui media soial seperti tutorial hijab di Youtube sehingga mereka dapat mengenakan hijab dengan berbagai model sesuai dengan keinginan dan kebutuhan mereka. Mereka terkadang memakai gamis, kardigan dan hijab dengan warna yang selaras dihiasi dengan akseosoris bros atau kalung serta sepatu yang selaras pula.

"Saya merupakan model di salah satu produk hijab di Kudus. Di dunia model saya menjadi lebih tahu dan up to date terhadap perkembangan hijab dan fashion dan menerapkannya ketika kuliah. Misalnya saya tidak selalui memakai rok setiap hari ketika kuliah. Saya terkadang mengenakan gamis yang cocok untuk anak muda, memakai kardigan atau rompi panjang, melengkapi dengan aksesoris seperti kalung dan bros, bahkan memakai sepatu 
dengan warna yang selaras dengan baju. Penampilan saya juga menginspirasi teman-teman sekelas sehingga mereka juga dapat tampil modis waktu kuliah". (wawancara dengan MT, 25 Januari 2017).

Media sosial tidak hanya memberi pengaruh pada perkembangan fashion dan hijab tetapi juga berdampak pada budaya konsumerisme para wanita muslimah termasuk mahasiswi STAIN Kudus. Tampilan fashion dan hijab di media sosial yang setiap saat berubah dan berkembang telah menarik perhatian wanita sehingga keinginan untuk membeli secara otomatis muncul. Sosok artis atau model berhijab yang marak menghiasi acara di televisi dapat menjadi sumber inspirasi para wanita muslimah. Hal ini menyebabkan pengeluaran atau kebutuhan belanja menjadi meningkat dari sebelumnya. Sebagaimana pernyataan (Bonadio \& Guimarães, 2016) bahwa penonton (masyarakat) melihat sosok model atau publik figure sebagai inspirasi termasuk fashion terbaru yang dipakai seperti bagaimana memadukan hijab dan aksesoris, memakai make-up, dan sebagainya sehingga merubah perilaku masyarakat termasuk tendensi budaya konsumerisme.

\section{Analisa Motif dan Ideologi Keislaman Mahasiswi}

Perilaku manusia dipengaruhi oleh lingkungan sekitar melalui penguatan (reinforcement), pembelajaran peniruan (observational learning), dan cara berfikir yang dimiliki seseorang terhadap sesuatu yang baru dan sebaliknya, yakni bagaimana tingkah laku seseorang dapat mempengaruhi orang lain di sekitar dan menghasilkan penguatan (reinforcemenet) peluang untuk diperhatikan oleh orang lain (observational opportunity) (Boeree, 2006). Menurut Bandura dalam Boeree (2006, hal. 5), ada beberapa tahap yang dilalui dalam proses belajar sosial. Tahap pertama Perhatian (attention), yakni jika kita ingin belajar sesuatu, kita harus memperhatikannya terlebih dahulu. Tahap kedua penyimpanan (retention), yakni kita harus mampu menyimpan informasi dan mengingat sesuatu yang kita perhatikan. Tahap ketiga yaitu Reproduksi (Reproduction), yaitu sesuatu yang sudah kita simpan dan ingat dapat kita terapkan di kehidupan nyata. 
Tahap keempat Motivasi (Motivation), yakni hasil dan bentuk perilaku seseorang dipengaruhi oleh motivasi dan alasan yang dimiliki setiap individu.

Terkait perilaku dan perubahan tatanan hijab dan fashion yang tejadi di kalangan mahasiswi STAIN Kudus, motif dan alasan yang membuat sebagian mahasisiwi STAIN Kudus jurusan PGRA mulai berubah salah satunya adalah faktor lingkungan. Beberapa mahasiswi jurusan PGRA semester delapan mengalami proses peniruan tatanan hijab dan fashion yang dikenakan oleh teman sekelasnya dan mahasiswi dari Jurusan lain atau dari media sosial baik peniruan secara langsung maupun sebagian. Sebelum menirukan tatanan hijab dan fashion dari lingkungan sekitar, mahasiswi terlebih dahulu memperhatikan dan mengamati penampilan hijab masyarakat sekitar. Pada proses ini mereka mengalami tahapan perhatian (attention). Tatanan model hijab dan fashion yang mereka lihat dan perhatikan dari berbagai sumber baik model langsung maupun melalui media sosial kemudian mereka simpan dan ingat untuk diterapkan di kehidupan nyata misalnya di kampus. Pada proses ini mereka mengalami tahapan penyimpanan (retention). Segala informasi mengenai hijab dan fashion yang telah diperoleh kemudian mulai mereka terapkan dalam kehidupan sehari-hari. Sebagian mahasiswi mulai menggunakan hijab dengan model baru dan fashion terkini. Mereka yang dahulu ketika kuliah selalu memakai rok panjang dan baju lengan panjang atau blouse, sekarang mulai berubah dengan memakai gamis, outer, kardigan. Selain itu, mereka mulai menambah aksesoris seperti Bros, kalung, sabuk untuk mempercantik penampilan. Dalam hal ini, mahasiswi mengalami proses tahapan reproduksi (reproduction). Penampilan baru mereka dalam berhijab dan berbusana kemudian mendapat respon, tanggapan atau komentar dari teman-teman mereka baik itu komentar positif maupun komentar negatif. Komentar positif inilah yang membuat mereka semakin percaya diri dan puas dalam berhijab dan berbusana dengan model terbaru serta berkreasi dalam fashion sekaligus menjadi penguatan bagi mereka (positive reinforcement). Sebaliknya, komentar negatif dari teman dan orang lain di sekitar dapat menjadikan mahasiswi tersebut menjadi kurang percaya diri atau menolak terhadap hijab dan fashion baru. Pada proses ini, mahasiswi mengalami proses tahapan motivasi (motivation). 
Ada dua motif mahasiswi STAIN dalam berhijab dan mengikuti fashion. Pertama, mengikuti teman, model, artis yang berhijab dan fashionable. Penampilan anggun dan cantik dalam berhijab dan berbusana yang ditunjukkan oleh teman mereka, model dan artis berhijab telah menarik perhatian mahasiswi STAIN Kudus jurusan PGRA sehingga menimbulkan keinginan untuk menirunya. Dalam hal ini, ada sebagian mahasiswi yang meniru secara langsung atau utuh, yakni sesuai dengan apa yang mereka lihat dan perhatikan.

"Saya sangat suka penampilan artis Zaskia Sungkar. Gaya hijabnya sederhana tapi tetap modis dibalut dengan rok, kardigan, outer dilengkapi dengan aksesoris seperti kalung dan sabuk. Kemudian, saya mencoba memakai hijab pasmina, memakai rok dengan baju dimasukkan dan memakai make-up sedikit untuk memadukan dengan busana yang saya pakai. Awalnya saya kurang percaya diri merubah tatanan hijab dan fashion, tapi setelah mendapat respon positif dari teman sekelas saya menjadi percaya diri dan selalu berusaha untuk berkreasi dengan hal-hal baru berhubungan dengan hijab dan fashion". (wawancara dengan MS, 25 Januari 2017)

Di sisi lain, ada mahasiswi yang merubah tampilan hijab dan fashion dengan meniru sebagian penampilan dari teman, artis idolanya. Mereka memodifikasi dengan kreasi mereka sendiri karena kurang percaya diri jika meniru persis dengan apa yang dilihatnya. Hal ini senada dengan pernyataan UL:

"Saya suka dengan perkembangan fashion saat ini. Berbagai model hijab dengan mudah saya lihat dan akses. Fashion juga terus berubah. Saya cenderung lebih suka memodifikasi gaya hijab orang lain atau artis. Saya mulai mengenakan gamis ketika kuliah. Akan tetapi dalam berhijab saya masih suka dengan model sederhana, hanya saja saya menambah hiasan seperti bros agar terkesan manis". (wawancara dengan UL, 25 Januari 2017).

Penampilan mahasiswi yang meniru tatanan hijab dan fashion orang lain secara langsung (utuh) dan sebagian dapat dilihat pada gambar 2. 


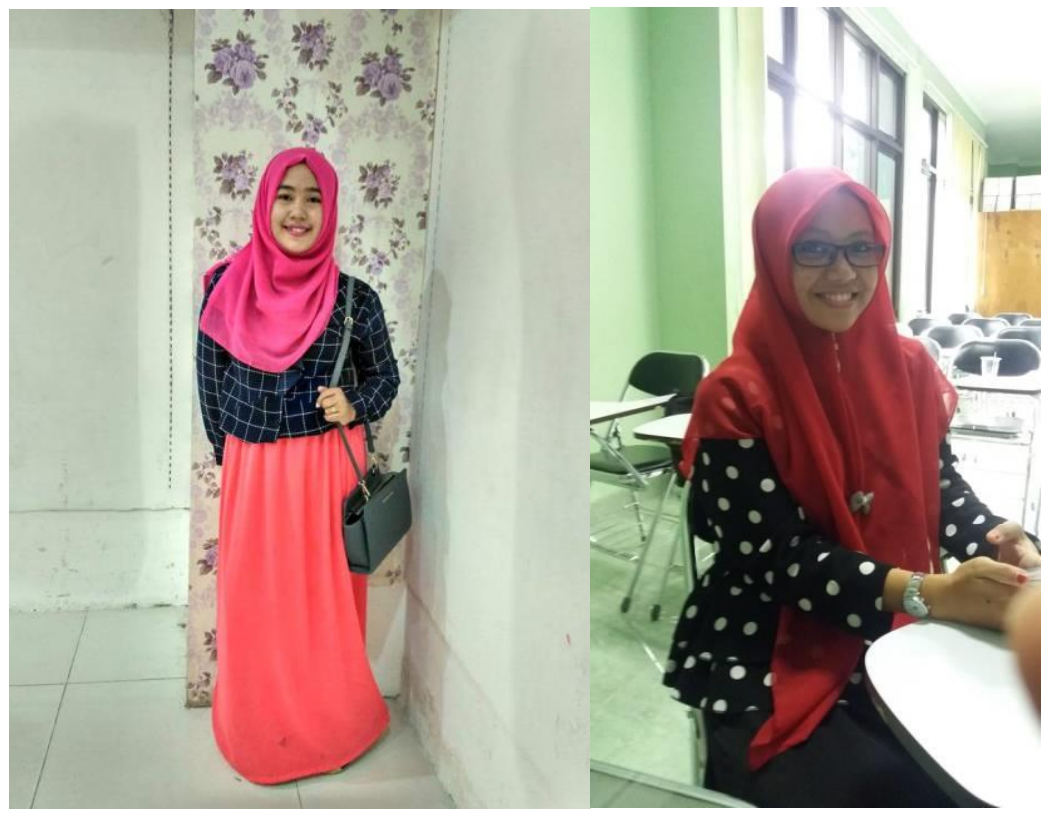

Gambar 2 Peniruan langsung (gambar kiri) dan peniruan sebagian (gambar kanan). Sumber (Koleksi Pribadi)

Motif kedua mahasiswi STAIN Kudus dalam berhijab dan fashion yaitu sebagai manifestasi modernitas. Di era globalisasi sekarang ini, setiap perkembangan dunia fashion dengan mudah diakses oleh para mahasiswi STAIN Kudus. Sebagian dari mereka mengikuti perkembangan model hijab dan fashion sebagai wujud modernitas. Modernitas ini ditunjukkan dengan banyaknya model hijab dilengkapi dengan corak dan warna yang mencolok. Untuk mempercantik penampilan, mereka menghias wajah mereka dengan balutan make-up. Lebih dari itu, sebagai wujud ekspresi diri mereka juga memiliki berbagai koleksi foto dan mengupload di media sosial. Semua itu dilakukan mereka sebagai salah satu usaha mengikuti modernitas. Kesan hijab yang dahulu terlihat kuno mulai terkikis. Para wanita muslimah termasuk mahasiswi STAIN Kudus kini terlihat cantik dan modis dengan berhijab lengkap dengan fashion dan aksesorisnya.

Setiap mahasiswi memiliki pandangan ideologi keislaman berbeda. Mahasiswi yang berpenampilan sangat modis dalam berhijab dan berbusana terutama meniru tatanan hijab dan fashion dari orang lain secara langsung cenderung berpendapat bahwa nilai keislaman dan ketaqwaan seseorang itu urusan setiap manusia dengan Allah. Mereka berpenampilan modis dan fleksibel dengan baju dimasukkan dipadukan dengan 
rok dengan warna mencolok merupakan sebagai bentuk ekspresi diri. Selama masih menjalankan syariat atau ajaran islam bagi mereka berpenampilan modis tidak menjadi masalah dan itu merupakan hak setiap wanita (Jones, 2007). Lebih jauh Droogsma (2007) mengungkapkan bahwa hijab mempunyai fungsi untuk mendefinisikan identitas Muslim, melakukan pemeriksaan perilaku, menolak objektifikasi seksual, memberikan lebih banyak rasa hormat, menjaga hubungan intim, dan memberikan kebebasan. Seorang muslimah yang berhijab dapat dipastikan akan melekat pada dirinya identitas seorang muslim, yaitu orang yang beragama Islam. Hijab juga dapat menahan seseorang untuk melakukan tindakan yang tidak sesuai dengan tuntunan Islam. Dalam hal ini dapat dikatakan bahwa secara tidak langsung hijab dapat menjadi pengawas dan benteng bagi seorang muslimah untuk berperilaku sesuai dengan ajaran Islam.

Di sisi lain, mahasiswi yang melakukan peniruan tatanan hijab dan fashion secara sebagian yakni melakukan modifikasi terhadap fashion yang dilihat beranggapan bahwa mengikuti perkembangan mode hijab itu boleh saja asalkan tetap memenuhi aturan dan ajaran islam. Misalnya: dalam membeli hijab, hendaknya tidak berbahan tipis agar tidak kelihatan rambut. Selain itu, kain hijab harus menutupi dada, baju tidak ketat dan tipis. Dalam hal ini, seorang wanita tidak boleh mengutamakan aspek modis saja dan mengabaikan aspek fungsi menutupi aurat. Dengan kata lain, sebagai mahasiswi muslimah mereka berpendapat bahwa aspek modis dan aspek fungsi hijab yang hakiki sebaiknya dapat dipadukan dengan sebaik mungkin. Seperti yang diuraikan oleh Droogsma (2007) bahwa hijab merupakan simbol kebebasan bagi seorang muslimah. Kebebasan ini apabila dikaitkan dengan konteks pemakaian hijab dikalangan mahasiswi muslim berupa kebebasan berekspresi terkait dengan model tatanan hijab. Model hijab yang modis serta kekinian tanpa sedikitpun meninggalkan aturan dan ketetapan Islam.

\section{Simpulan}

Hijab dan fashion semakin dikenal dan diikuti oleh sebagian besar wanita muslimah termasuk mahasiswi STAIN Kudus terutama jurusan PGRA. Setelah masuk dunia perkuliahan, mereka mulai mengenal perkembangan hijab dan fashion. Berbagai hijab, aksesoris dan fashion dikoleksi oleh mereka seperti gamis, kardigan,outer dan 
sebagainya. Penampilan mereka berubah menjadi trendy dan terinspirasi dari berbagai model hijab. Beberapa mahasiswi jurusan PGRA mengalami proses peniruan tatanan hijab dan fashion yang dikenakan oleh teman sekelasnya dan mahasiswi dari Jurusan lain atau dari media sosial baik peniruan secara langsung maupun sebagian. Mereka terlebih dahulu mengamati dan memperhatikan hijab dan fashion (attention). Tatanan model hijab dan fashion yang mereka lihat dan perhatikan dari berbagai sumber kemudian mereka simpan dan ingat untuk diterapkan (retention). Setelah itu, mereka mulai menggunakan hijab dengan model baru dan fashion terkini (reproduction). Penampilan baru mereka dalam berhijab dan berbusana kemudian mendapat respon dari orang lain (positive reinforcement). Hal ini merupakan bentuk motivasi (motivation) sekaligus menjadi penguatan bagi mereka untuk berhijab dan berbusana. Mahasiswi STAIN Kudus jurusan PGRA masing-masing memiliki ideologi keislaman yang berbeda. Mereka yang berpenampilan sangat modis dan melakukan peniruan secara langsung berpendapat bahwa nilai keislaman dan ketaqwaan seseorang itu urusan setiap manusia dengan Allah SWT. Hal tersebut sebagai bentuk ekspresi diri mereka. Di sisi lain, mahasiswi yang melakukan peniruan tatanan hijab dan fashion secara sebagian yakni melakukan modifikasi terhadap fashion yang dilihat beranggapan bahwa bahwa aspek modis dan aspek fungsi hijab yang hakiki sebaiknya dapat dipadukan dengan sebaik mungkin. 


\section{Referensi}

Almila, A. M. (2016a). Fashion, anti-fashion, non-fashion and symbolic capital: The uses of dress among muslim minorities in Finland. Fashion Theory - Journal of Dress Body and Culture, 20(1), 81-102. http://doi.org/10.1080/1362704X.2015.1078136

Almila, A. M. (2016b). Fashion, anti-fashion, non-fashion and symbolic capital: The uses of dress among muslim minorities in Finland. Fashion Theory - Journal of Dress Body and Culture, 20(1), 81-102. http://doi.org/10.1080/1362704X.2015.1078136

Alyusi, S. D. (2016). Media Sosial: Interaksi, Identitas dan Modal Sosial. Jakarta: Prenadamedia Group.

Arzu Ünal, R., \& Moors, A. (2012). Formats, fabrics, and fashions: Muslim headscarves revisited. Material Religion, $8(3), \quad 308-329$. http://doi.org/10.2752/175183412X13415044208835

Beta, A. R. (2014). Hijabers: How young urban muslim women redefine themselves in Indonesia. International Communication Gazette, 76(4-5), 377-389. http://doi.org/10.1177/1748048514524103

Boeree, C. G. (2006). Personality Theories Albert Bandura. USA: Shippensburg University.

Bonadio, M. C., \& Guimarães, M. E. A. (2016). Telenovelas: Consumption and dissemination of a Brazilian fashion. Fashion Theory - Journal of Dress Body and Culture, 20(2), 209-228. http://doi.org/10.1080/1362704X.2016.1133591

Boulanouar, A. W. (2006). The Notion of Modesty in Muslim Women's Clothing: An Islamic Point Of View. New Zealand Journal of Asian Studies, 8(2), 134-156.

Chen, L., Akat, H. D., Xin, C., \& Song, S. W. (2014). Rethinking Hijab: Multiple Themes in Muslim Women's Perception of the Hijab Fashion. In International Conference on Communication, Media, Technology and Design (hal. 208-214).

Droogsma, R. A. (2007). Redefining Hijab: American Muslim women's standpoints on veiling. Journal of Applied Communication Research, 35(3), 294-319. http://doi.org/10.1080/00909880701434299 
Jones, C. (2007). Fashion and faith in urban Indonesia. Fashion Theory - Journal of Dress Body and Culture, 11(2-3), 211-232. http://doi.org/10.2752/136270407X202763

Lewis, R. (2007, Desember). Veils and sales: Muslims and the spaces of postcolonial fashion retail. Fashion Theory - Journal of Dress Body and Culture. http://doi.org/10.2752/175174107X250235

Rocamora, A. (2012). Hypertextuality And Remediation In The Fashion Media. Journalism Practice, 6(1), 92-106. http://doi.org/10.1080/17512786.2011.622914

Shihab, Q. (2012). Jilbab, Pakaian Wanita Muslimah: Pandangan Ulama Masa Lalu dan Cendikiawan Kontemporer. Jakarta: Lentera Hati. 